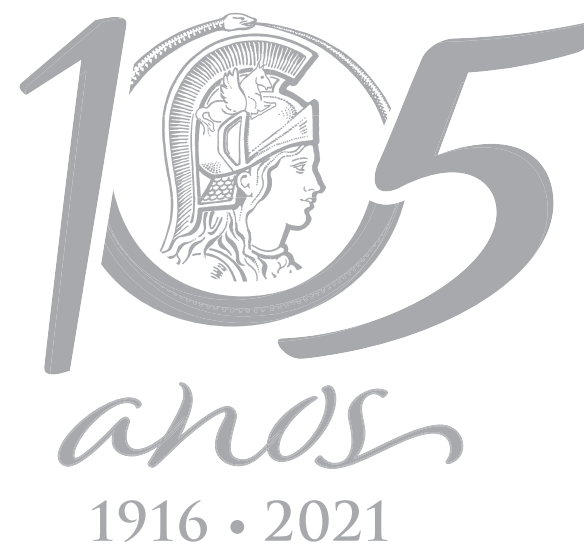

\title{
MICROBIOLOGY
}

\section{Carbonate and silicate dissolving bacteria isolated from home-made yogurt samples}

\author{
FURKAN ORHAN, ABDULLAH DEMIRCI \& ARZU GORMEZ
}

\begin{abstract}
In the current study, twenty-eight bacterial strains were isolated from homemade yogurt samples from Ağrı Province, Turkey. The bacterial strains were identified by conventional and molecular techniques. Among the twenty- eight isolates, seventeen isolates were identified according to the $16 \mathrm{~S}$ rDNA region and determined to belong to five different genus including Sphingomonas (8 isolates), Burkholderia (5 isolates), Lactobacillus (2 isolates), Lactococcus (1 isolate), Staphylococcus (1 isolate). In this study, the presence of Burkholderia in home-made yogurt samples were reported for the first time, whereas Sphingomonas was detected for the second time. We also investigated the carbonate $\left(\mathrm{CaCO}_{3}\right.$ and $\left.\mathrm{MgCO}_{3}\right)$ and silicate $\left(\mathrm{CaSiO}_{3}\right.$ and $\left.\mathrm{MgSiO}_{3}\right)$ dissolving potential of seventeen bacterial isolates. Among these seventeen bacterial isolates, fifteen bacterial isolates have $\mathrm{CaCO}_{3}$-dissolving and 10 bacterial isolates have $\mathrm{MgCO}_{3}$-dissolving potential. The silicates dissolution ability was relatively less than that of carbonates dissolving. We observed that six bacterial isolates have $\mathrm{CaSiO}_{3}$ and only two bacterial isolates have $\mathrm{MgSiO}_{3}$ dissolution abilities. In conclusion, this work clearly shows the diversity of bacteria existing in fermented cow milk samples in Ağrı Province, Turkey, which could be considered as valuable sources for lactic acid bacteria ( $L A B)$ isolation and further probiotic potential.
\end{abstract}

Key words: Home-made yogurt, LAB, carbonate, silicate dissolving.

\section{INTRODUCTION}

Fermentation occurs primarily in an anaerobic process in which compounds such as sugars are converted to other compounds such as alcohols and results in energy production to be used by cells and microorganisms. The microorganisms involved in fermentation process can reduce the contamination risks of foods by producing compounds such as antimicrobials, ethanol and organic acids. Besides, fermentation process can result in an improved taste and texture of the starting material (milk, meat, vegetable etc.). Most of bacteria have enzymatic capacity for fermentation and produce lactic acid. Microorganisms can be found in fermented products either naturally or they can be added as starter culture and each of which are responsible for forming trademark tastes, textures and flavours of the fermented foods. As fermented products have nutritional value and variety of sensory attributes, they became increasingly popular as daily intake products in many countries. Popular fermented products consumed in various countries include kefir, sauerkraut, kimchi, cortido, sourdough, kvass, kombucha, pulque, kaffir beer, ogi, Igunaq, miso, tepa, dosa, cheddar and stilton cheeses, surströmming, crème fraîche, fermented sausage, wine and yogurt which are made of milk, vegetable and meat (Chilton et al. 2015). Among all foods in the marketplace yogurt was shown to be one of the most biologically active and highly nutritious protein-rich product produced 
in the fermentation process. Yogurt contains higher levels of carbohydrate, calcium, protein and a variety of group B vitamins compared to milk (Deeth \& Tamime 1981, Gurr 1987). Yogurt is a semisolid fermented milk product obtained in the presence of Streptococcus thermophilus and Lactobacillus bulgaricus, but, other bacteria such as Lactobacillus jugurti, Lactobacillus helveticus, Lactobacillus casei, and several species of Bifidobacterium are also commonly used. During the fermentation process these mentioned bacteria convert the carbohydrate into lactic acid and other metabolites, hydrolyse caseins into free amino acids and peptides and digest fat into free fatty acids of the milk. Worldwide, yogurt has increased its popularity over the past few decades due to its flavour, texture, aroma and many health benefits (Shah \& Champagne 2015, Chandan 2015). The health benefits of yogurt include type 2 diabetes, obesity, gastrointestinal benefits, reduction in cardio-metabolic diseases and serum cholesterol, immuno-modulatory effects, control of infections, anti-carcinogenesis, production of vitamins and control of pathogenic organisms, weight management, skin health (Ley et al. 2006, Round \& Mazmanian 2009, Astrup 2014, Marette \& Picard-Deland 2014, Morelli 2014).

The aim of the present study was to isolate and identify the lactic acid bacteria in local yogurt samples from villages situated in the Ağri, Province, Turkey. For this purpose, eleven yogurt samples were collected from 5 different villages and the isolates obtained from the yogurt samples were tested for their characteristics. It is known that many lactic acid bacteria have carbonate dissolution potential due to their acid production. For this reason, we have also investigated seventeen bacterial isolates for their carbonate and silicate dissolution potential.

\section{MATERIALS AND METHODS}

Yogurt samples: a total of eleven yogurt samples were collected from five different villages in Ağrı Province, Turkey. The samples were collected in sterile bottles and kept at $4{ }^{\circ} \mathrm{C}$ for further use. The isolates of 5 different villages [(Patnos-Akyemiş), (Ağrı center-Konuktepe), (Hamur-Karabal), (Eleşkirt-Yeşilova) and (Tutak-Güneşgören)] were (AD1-AD8), (AD9-AD17), (AD18-AD25), (AD26-AD30) and (AD31-AD32), respectively.

Isolation of bacterial strains: The collected yogurt samples were diluted 10 -fold in sterile physiological saline solution $(0.9 \% \mathrm{NaCl})$. One $\mathrm{mL}$ of each diluted yogurt sample was mixed with MRS agar medium and then incubated at $30{ }^{\circ} \mathrm{C}$ for 48-72 h. The colonies with distinct morphological differences (based on color, shape and size, rough or smooth surface) were picked up with a loop and then spreaded on MRS agar medium for the purification of each isolate.

\section{Characterization of Isolates}

The isolates were screened for their Gram reaction as described previously (Wood \& Krieg 1989) and followed by the determination of motility of the isolates with wet mounts. Additional tests were performed for the characterization of the isolates, which included determination of the oxidase and catalase, reduction of the nitrite and nitrate, utilization of arginine, hydrolysis of gelatine, urea, casein, starch and esculine, acid production from carbohydrates (galactose, mannose, inositol, sorbitol, sucrose, lactose, maltose and xylose) (Wayne et al. 1974, Barrow \& Feltham 2004, Chuard \& Reller 1998). The antibiotic susceptibility of the isolates was determined by using the disk diffusion method as described previously (Wayne 2002).

The genomic DNA isolation from the isolates was performed with a DNA extraction 
kit (Qiagen). For the amplification of the 16S rDNA region, the universal primers (27F 5'-AGAGTTTGATCCTGGCTCAG-3'; 1492R 5'-GGTTACCTTGTTACGACTT-3') were used.

The amplification of $16 \mathrm{~S}$ rRNA region was performed as described previously (Orhan \& Gulluce 2015). Afterwards, the PCR products were sent to Macrogen (http://www.macrogen. com) for sequence analysis. The sequence data of the seventeen isolates were analysed and the results were blasted at the NCBI sequence database.

\section{Screening of Carbonates $\left(\mathrm{CaCO}_{3}\right.$ and $\mathrm{MgCO}_{3}$ ) and Silicates $\left(\mathrm{CaSiO}_{3}\right.$ and $\mathrm{MgSiO}_{3}$ ) dissolution potential}

In order to determine the carbonates $\left(\mathrm{CaCO}_{3}\right.$ and $\mathrm{MgCO}_{3}$ ) dissolution potential of bacterial isolates, the method previously described was used (Cacchio et al. 2004). The medium used for $\mathrm{CaCO}_{3}$ dissolution potential was as follows (per liter): glucose, $20 \mathrm{~g} ; \mathrm{NaCl}, 10 \mathrm{~g} ; \mathrm{MgCl}_{2}, 3 \mathrm{~g}$; $\mathrm{MgSO}_{4} .7 \mathrm{H}_{2} \mathrm{O}, 0.5 \mathrm{~g} ; \mathrm{KCl}, 0.4 \mathrm{~g}$; $\left(\mathrm{NH}_{4}\right)_{2} \mathrm{SO}_{4}, 0.2 \mathrm{~g}$; agar, $15 \mathrm{~g}$ and $\mathrm{CaCO}_{3}, 5.0 \mathrm{~g}$. Similar to the $\mathrm{CaCO}_{3}$ dissolution medium, same amount of $\mathrm{MgCO}_{3}$ was used instead $\mathrm{CaCO}_{3}$ for the $\mathrm{MgCO}_{3}$ dissolution medium. The zone of clearance around the colonies was considered as positive for $\mathrm{CaCO}_{3}$ and $\mathrm{MgCO}_{3}$ dissolution capabilities.

For the dissolution of silicates, soil extract was prepared as follows: $1 \mathrm{~kg}$ of garden land soil was added to $1000 \mathrm{~mL}$ of tap water and then autoclaved at $121^{\circ} \mathrm{C}$ for $30 \mathrm{~min}$. After then, the soil sample was filtered with a Whatman filter paper (No:1) and it was completed to a final volume of $1000 \mathrm{ml}$ with tap water. For the dissolution of $\mathrm{CaSiO}_{3}$, we used the method previously described (Bunt \& Rovira 1955). The medium was prepared as follows (per liter): $10 \mathrm{~g}$ peptone, $20 \mathrm{~g}$ glucose, $0.1 \mathrm{~g} \mathrm{MgCl}_{2}, 0.01 \mathrm{~g} \mathrm{FeCl}_{3}, 1 \mathrm{~g}$ yeast extract, $0.5 \mathrm{~g}\left(\mathrm{NH}_{4}\right)_{2} \mathrm{SO}_{4}, 0.4 \mathrm{~g} \mathrm{Na}_{2} \mathrm{HPO}_{4}, 15 \mathrm{~g}$ agar and $2.5 \mathrm{~g}$ insoluble $\mathrm{CaSiO}_{3}$ along with $500 \mathrm{ml}$ of soil extract and the pH was adjusted to 7.20. Similar to the $\mathrm{CaSiO}_{3}$ dissolution medium, same amount of $\mathrm{MgSiO}_{3}$ was used instead $\mathrm{CaSiO}_{3}$ for the $\mathrm{MgSiO}_{3}$ dissolution medium. The bacterial isolates were incubated at $30^{\circ} \mathrm{C}$ for 2 weeks on calcium silicate agar and magnesium silicate agar media for $\mathrm{CaSiO}_{3}$ and $\mathrm{MgSiO}_{3}$ dissolution potential, respectively. The zone of clearance around the colonies was considered as positive for $\mathrm{CaSiO}_{3}$ and $\mathrm{MgSiO}_{3}$ dissolution capabilities.

\section{RESULTS}

In the current paper, the twenty-eight bacterial isolates (AD1- AD32) were characterized by conventional and molecular methods. In conventional methods, the morphology, motility and Gram of the twenty-eight bacterial isolates were investigated. As biochemical and physiological parameters catalase and oxidase tests, nitrate and nitrite reduction, arginine utilization, hydrolysis of gelatine, urea, casein, starch and esculin were investigated. The antibiotic susceptibility (neomycin and tetracycline) of the bacterial isolates was also investigated. In addition, the acid production from carbohydrates (glucose, galactose, mannose, inositol, sorbitol, sucrose, lactose, maltose and xylose) was tested. The DNA extraction of twenty-eight bacterial isolates were performed for molecular identification method. Afterwards, the amplification of $16 \mathrm{~S}$ rRNA genes was performed and then the amplified 16S rRNA product was sequenced. However, only seventeen bacterial isolates could be characterized due to sequencing difficulties of Burkholderia and Sphingomonas.

As the bacterial isolates were isolated from yogurt samples, they were thought to have probiotic potential, so the isolates were tested for their probiotic potential as pH (2.0, 2.5, 3.0, 4.40 and 9.60$)$, bile salt [cholic acid $(0.05,0.3$ and $0.5)(\mathrm{w} / \mathrm{v})]$, temperature $\left(10\right.$ and $\left.45^{\circ} \mathrm{C}\right)$ and salt $(\mathrm{NaCl})(6.5,12$ and 18$)$ tolerance. 
The phenotypic characteristics of the isolates are given in Table I.

In respect to gelatine hydrolysis, only one isolate (AD16) was positive, seven isolates were not determined and twenty isolates were negative. None of the isolates were able to hydrolysis urea, casein or starch. Only one isolate (AD28) was sensitive to neomycin, while all the others were resistant to both neomycin and tetracycline (Table II).

Acid production from carbohydrates tested (glucose, galactose, mannose, inositol, sorbitol, sucrose, lactose, maltose and xylose) were recorded to be variable as summarized in Table III.

Table I. Phenotypic characteristics of the isolates.

\begin{tabular}{|c|c|c|c|c|c|c|c|c|}
\hline $\begin{array}{l}\text { Isolate } \\
\text { code }\end{array}$ & $\begin{array}{l}\text { Gram } \\
(\mathrm{KOH})\end{array}$ & Motility & $\begin{array}{c}\text { Cell } \\
\text { morphology }\end{array}$ & Catalase & Oxidase & $\begin{array}{l}\text { Nitrate } \\
\text { reduction }\end{array}$ & $\begin{array}{l}\text { Nitrite } \\
\text { reduction }\end{array}$ & $\begin{array}{c}\text { Arginine } \\
\text { utilization }\end{array}$ \\
\hline AD1 & - & - & Rod & + & - & - & - & - \\
\hline AD2 & - & - & Rod & + & - & - & - & - \\
\hline AD3 & - & - & Rod & + & - & - & + & - \\
\hline AD4 & - & - & Rod & + & - & - & + & - \\
\hline AD5 & - & - & Rod & + & - & - & + & - \\
\hline AD6 & - & - & Rod & + & - & - & + & - \\
\hline AD7 & - & - & Rod & + & - & - & + & - \\
\hline AD8 & - & - & Rod & + & - & - & + & - \\
\hline AD9 & - & - & Rod & + & - & - & + & - \\
\hline AD10 & - & - & Rod & + & - & - & + & - \\
\hline AD11 & - & - & Rod & + & - & - & - & - \\
\hline AD12 & - & - & Rod & + & - & - & + & - \\
\hline AD13 & - & - & Rod & + & - & - & - & - \\
\hline AD14 & - & - & Rod & - & - & - & - & - \\
\hline AD15 & - & - & Rod & + & - & - & + & - \\
\hline AD16 & - & - & Oval & - & - & - & - & - \\
\hline AD17 & - & - & Rod & + & - & - & - & - \\
\hline AD18 & - & - & Oval & + & - & - & + & - \\
\hline AD19 & - & - & Oval & + & - & - & - & - \\
\hline AD20 & - & - & Rod & + & - & - & - & - \\
\hline AD21 & - & - & Rod & + & - & - & - & + \\
\hline AD22 & - & - & Rod & + & - & - & - & - \\
\hline AD23 & - & - & Rod & - & - & - & - & - \\
\hline AD24 & - & - & Oval & + & - & - & - & - \\
\hline AD28 & + & - & Coccoid & + & - & - & + & + \\
\hline AD30 & + & - & Coccoid & + & - & - & + & + \\
\hline AD31 & + & - & Rod & - & - & - & - & - \\
\hline AD32 & + & - & Rod & - & - & - & - & + \\
\hline
\end{tabular}

According to the blast analysis of seventeen bacterial isolates, five isolates (AD2, AD3, AD5, $A D 6$ and $A D 13)$ were Burkholderia sp., eight isolates (AD4, AD8, AD10, AD11, AD12, AD14, AD20 and AD21) were Sphingomonas sp., one isolate (AD28) was Staphylococcus epidermidis, one isolate (AD30) was Lactococcus lactis and two isolates (AD31 and AD32) were Lactobacillus (Lactobacillus paracasei and Lactobacillus casei, respectively) (Table IV).

Majority of the isolates grew at a $\mathrm{pH}$ range from 2.0 to 9.60 (Table V). One isolate (AD9) did not grow at the $\mathrm{pH} 9.60$ as shown in the Table $\mathrm{V}$. Considering the bile salt tolerance, most of the isolates grew in the 0.005 and $0.3 \%$ bile salt, while ten isolates grew in the $0.5 \%$ bile salt. 
The temperature tolerance test showed that one isolate (AD32) did not grow at $10{ }^{\circ} \mathrm{C}$ and one isolate (AD23) did not grow at $45^{\circ} \mathrm{C}$, while all the others grew at both 10 and $45^{\circ} \mathrm{C}$. Twenty isolates grew in $6.5 \% \mathrm{NaCl}$, nineteen isolates grew in $12 \% \mathrm{NaCl}$, and fifteen isolates slightly grew in $18 \% \mathrm{NaCl}$ (Table V).

Among seventeen bacterial isolates, fifteen bacterial isolates were able to dissolve $\mathrm{CaCO}_{3}$ and ten bacterial isolates were able to dissolve $\mathrm{MgCO}_{3}$. While, six bacterial isolates (AD13, AD14, AD20, AD30, AD31 and AD32) were able to dissolve $\mathrm{CaSiO}_{3}$, only two isolates (AD31 and AD32) were able to dissolve $\mathrm{MgSiO}_{3}$ (Table VI and Figure 1).
The results of bacterial isolates producing yogurt/yogurt-like product are shown in Figure 2.

\section{DISCUSSION}

The word 'yoghurt' was derived from the Turkish word 'jugurt' or 'yoğurt' and in different countries it has various names as 'Tiaourti' in Greece, 'Cieddu' in Italy, 'Kissel Mleka' in Balkans, 'Mezzoradu' in Sicily, 'Leben/Laben' in Scandinavian, 'Zabady' in Egytp and Sudan, 'Tarho' in Hungary, 'Mast/Dough' in Iran and

Table II. Phenotypic characteristics (hydrolysis of various substrates and antibiotic susceptibility) of the isolates.

\begin{tabular}{|c|c|c|c|c|c|c|c|}
\hline \multirow[t]{2}{*}{ Isolate code } & \multicolumn{5}{|c|}{ Hydrolysis of } & \multicolumn{2}{|c|}{ Antibiotic Susceptibility (mm) } \\
\hline & Gelatin & Urea & Casein & Starch & Esculin & Neomycin & Tetracycline \\
\hline AD1 & - & - & - & - & + & $R$ & $\mathrm{R}$ \\
\hline AD2 & - & - & - & - & + & $\mathrm{R}$ & $\mathrm{R}$ \\
\hline AD3 & - & - & - & - & + & $\mathrm{R}$ & $\mathrm{R}$ \\
\hline AD4 & - & - & - & - & + & $\mathrm{R}$ & $\mathrm{R}$ \\
\hline AD5 & - & - & - & - & - & $\mathrm{R}$ & $\mathrm{R}$ \\
\hline AD6 & - & - & - & - & - & $\mathrm{R}$ & $\mathrm{R}$ \\
\hline AD7 & ND & - & - & - & + & $\mathrm{R}$ & $\mathrm{R}$ \\
\hline AD8 & - & - & - & - & + & $\mathrm{R}$ & $\mathrm{R}$ \\
\hline AD9 & ND & - & - & - & + & $\mathrm{R}$ & $\mathrm{R}$ \\
\hline AD10 & - & - & - & - & + & $\mathrm{R}$ & $\mathrm{R}$ \\
\hline AD11 & - & - & - & - & + & $\mathrm{R}$ & $\mathrm{R}$ \\
\hline AD12 & - & - & - & - & + & $\mathrm{R}$ & $\mathrm{R}$ \\
\hline AD13 & - & - & - & - & + & $\mathrm{R}$ & $\mathrm{R}$ \\
\hline AD14 & - & - & - & - & + & $\mathrm{R}$ & $\mathrm{R}$ \\
\hline AD15 & - & - & - & - & - & $\mathrm{R}$ & $\mathrm{R}$ \\
\hline AD16 & + & - & - & - & + & $\mathrm{R}$ & $\mathrm{R}$ \\
\hline AD17 & ND & - & - & - & + & $\mathrm{R}$ & $\mathrm{R}$ \\
\hline AD18 & - & - & - & - & + & $\mathrm{R}$ & $\mathrm{R}$ \\
\hline AD19 & - & - & - & - & + & $\mathrm{R}$ & $\mathrm{R}$ \\
\hline AD20 & ND & - & - & - & - & $\mathrm{R}$ & $\mathrm{R}$ \\
\hline AD21 & - & - & - & - & - & $\mathrm{R}$ & $\mathrm{R}$ \\
\hline AD22 & ND & - & - & - & - & $\mathrm{R}$ & $\mathrm{R}$ \\
\hline AD23 & - & - & - & - & - & $\mathrm{R}$ & $\mathrm{R}$ \\
\hline AD24 & - & - & - & - & + & $\mathrm{R}$ & $\mathrm{R}$ \\
\hline AD28 & - & - & - & - & - & 18 & $R$ \\
\hline AD30 & ND & - & + & - & + & $\mathrm{R}$ & $\mathrm{R}$ \\
\hline AD31 & ND & - & - & - & + & $\mathrm{R}$ & $\mathrm{R}$ \\
\hline AD32 & - & - & - & - & + & $\mathrm{R}$ & $\mathrm{R}$ \\
\hline
\end{tabular}

-: Negative, +: Positive, ND: Not determined, R: Resistant, mm: millimeter. 
Table III. Phenotypic characteristics (acid production from various sugars) of the isolates.

\begin{tabular}{|c|c|c|c|c|c|c|c|c|c|}
\hline \multirow{2}{*}{ Isolate code } & \multicolumn{9}{|c|}{ Acid production from } \\
\hline & Glucose & Galactose & Mannose & Inositol & Sorbitol & Sucrose & Lactose & Maltose & Xylose \\
\hline AD1 & + & + & + & - & - & + & + & - & + \\
\hline AD2 & + & + & + & - & - & + & + & - & + \\
\hline AD3 & + & + & + & - & - & + & + & - & + \\
\hline AD4 & + & + & + & - & - & + & + & - & + \\
\hline AD5 & + & + & + & - & - & + & + & - & + \\
\hline AD6 & - & - & - & - & - & - & - & - & - \\
\hline AD7 & + & + & + & - & + & + & + & - & + \\
\hline AD8 & - & + & Slight & - & - & + & + & - & + \\
\hline AD9 & + & + & + & - & - & + & + & - & + \\
\hline AD10 & - & + & + & - & - & + & + & - & + \\
\hline AD11 & + & + & + & - & + & + & + & - & + \\
\hline AD12 & + & + & + & - & - & + & + & - & + \\
\hline AD13 & + & + & + & - & - & + & + & - & + \\
\hline AD14 & + & + & + & - & - & + & + & - & + \\
\hline AD15 & + & + & + & - & - & + & + & - & + \\
\hline AD16 & + & + & + & - & + & + & + & - & + \\
\hline AD17 & - & + & + & - & - & + & + & - & + \\
\hline AD18 & + & + & + & - & - & + & + & - & + \\
\hline AD19 & + & + & + & - & - & + & + & - & + \\
\hline AD20 & + & + & + & - & - & + & + & - & + \\
\hline AD21 & + & + & + & - & - & + & + & - & + \\
\hline AD22 & + & + & + & - & - & + & + & - & + \\
\hline AD23 & - & + & + & - & - & + & - & - & + \\
\hline AD24 & - & + & + & - & - & + & + & - & + \\
\hline AD28 & - & + & + & - & - & + & + & - & + \\
\hline AD30 & - & + & + & - & - & - & - & + & - \\
\hline AD31 & - & + & + & - & + & + & + & - & + \\
\hline AD32 & - & - & - & - & + & Slight & + & - & + \\
\hline
\end{tabular}

-: Negative, +: Positive.

Afghanistan, 'Villi' in Finland, 'Roba' in Iraq, 'Skyr' in Iceland, 'Dahi/Dadhi/Dahee' in India, Bangladesh and Nepal, 'Mazun' in Armenia and 'Yoghurt/Yogurt/Yaourt' in the rest of the world (Tamime \& Deeth 1980). Yogurt is generally prepared from cow's milk, however, milk from sheep, water buffaloes, yaks, horses, and camels can also be used (Donovan \& Shamir 2014). The texture, taste and aroma of the yogurt vary according to the type of milk used, the method used for milk processing and the starter cultures used in the yogurt production (Chandan \& Kilara 2013). It has been documented that the use of defined starter cultures led to a product with better aroma, acceptability, taste and appearance than spontaneously fermented beverages (Peyer et al. 2016). For this reason, researchers are attempting to obtain better result in producing yogurt by improving the methods for the yogurt production and isolation of new strains capable in yogurt fermentation. In this regard, members of Lactobacillus, Streptococcus, Weissella, Pediococcus, Enterococcus and Leuconostoc from various yogurt, cheese and milk samples have been documented (Nakhdjavani et al. 1996, Azadnia \& Khan Nazer 2009, Ebrahimi et al. 2011, RoushanZadeh et al. 2014, Velikova et al. 2018).

In home-made yogurt and raw milk samples collected in Pakistan, several unexpected bacteria including Sphingomonas, Pseudomonas and 
Table IV. Identification of the isolates.

\begin{tabular}{|c|c|c|c|c|}
\hline Isolate code & Accession no. & Nearest type strain & Sequence length & Sequence identity (\%) \\
\hline AD2 & MK454715 & Burkholderia sp. & 1397 & 99 \\
\hline AD3 & MK454716 & Burkholderia sp. & 1380 & 99 \\
\hline AD4 & MK454717 & Sphingomonas sp. & 1167 & 99 \\
\hline AD5 & MK454718 & Burkholderia sp. & 1382 & 99 \\
\hline AD6 & MK454719 & Burkholderia sp. & 1407 & 99 \\
\hline AD8 & MK454720 & Sphingomonas sp. & 1050 & 97 \\
\hline AD10 & MK454721 & Sphingomonas sp. & 1153 & 99 \\
\hline AD11 & MK454722 & Sphingomonas sp. & 1126 & 99 \\
\hline AD12 & MK454723 & Sphingomonas sp. & 1173 & 99 \\
\hline AD13 & MK454724 & Burkholderia sp. & 1184 & 100 \\
\hline AD14 & MK454725 & Sphingomonas sp. & 1077 & 99 \\
\hline AD20 & MK454726 & Sphingomonas sp. & 1080 & 98 \\
\hline AD21 & MK454727 & Sphingomonas sp. & 1051 & 99 \\
\hline AD28 & MK454728 & Staphylococcus epidermidis & 1372 & 99 \\
\hline AD30 & MK454729 & Lactococcus lactis & 1383 & 99 \\
\hline AD31 & MK454730 & Lactobacillus paracasei & 1373 & 99 \\
\hline AD32 & MK454731 & Lactobacillus casei & 1366 & 99 \\
\hline
\end{tabular}

Bacillus have been reported (Asma \& Qazi 2014). In accordance with the data in above line, the genus Sphingomonas has also been detected in our study. Indeed, this genus have been isolated from a variety of sources such as drinking water system, hospital water equipment's, seawater, river, waste water, sea ice, soil, mineral water, milk of bovine and human (Ferreira et al. 1996, Geldreich 1996, Bowman et al. 1997, Vachée et al. 1997, Oie et al. 1998, Gauthier et al. 1999, Tabata et al. 1999, Hunt et al. 2011, Kuehn et al. 2013, Zhang et al. 2015). According to the available literature, this is the second paper documenting the presence of the genus Sphingomonas in home-made yogurt samples.

Other unexpected bacteria isolated from the yogurt samples in this study was Burkholderia. The members of this genus are able to inhabit diverse sources including soil, water, fungus, plant rhizosphere, infected human and animals (Burkholder 1950, Vial et al. 2008, Morelli 2014, Eberl \& Vandamme 2016). Interestingly, they have both pathogenic and beneficial members. For example, Burkholderia mallei, B. pseudomallei and B. solanacearum are human, animal and plant pathogens, respectively (Burkholder 1950, Eberl \& Vandamme 2016). The beneficial member of this genus is $B$. tropica which can inhibit the growth of pathogenic fungi such as Colletotrichum, Fusarium and Sclerotium (Tenorio-Salgado et al. 2013). The other beneficial member of this genus is $B$. vietnamiensis which has plant (rice) growth promoting activities (Van et al. 2000). The data obtained from the $\mathrm{pH}$ and bile salt (cholic acid) tolerances in this study showed that the bacterial isolates may have probiotic potential as most of the isolates (except for the known pathogen, Staphylococcus epidermis) have both $\mathrm{pH}$ and bile salt tolerances.

Among the twenty-eight bacterial isolates, seventeen isolates have been identified in terms of their 16S rRNA gene sequences region. The data of the 16S rRNA gene sequences region shows that among these seventeen isolates, five isolates ( $A D 2, A D 3, A D 5, A D 6$ and AD13) belong to the genus Burkholderia, eight isolates (AD4, AD8, AD10, AD11, AD12, AD14, AD20 and AD21) belong to the genus Sphingomonas, two isolates (AD31 
Table V. Phenotypic characteristics (tolerance of $\mathrm{pH}$, bile salt, temperature and salt) of the isolates.

\begin{tabular}{|c|c|c|c|c|c|c|c|c|c|c|c|c|c|}
\hline \multirow[t]{2}{*}{$\begin{array}{l}\text { Isolate } \\
\text { code }\end{array}$} & \multicolumn{5}{|c|}{ pH tolerance } & \multicolumn{3}{|c|}{$\begin{array}{l}\text { Bile salt (cholic acid) } \\
\text { tolerance }(\%)\end{array}$} & \multicolumn{2}{|c|}{$\begin{array}{c}\text { Temperature } \\
\text { tolerance } \\
\left({ }^{\circ} \mathrm{C}\right)\end{array}$} & \multicolumn{3}{|c|}{$\begin{array}{l}\text { Salt tolerance (\% } \\
\mathrm{NaCl})\end{array}$} \\
\hline & 2.0 & 2.5 & 3.0 & 4.40 & 9.60 & 0.05 & 0.3 & 0.5 & 10 & 45 & 6.5 & 12 & 18 \\
\hline AD1 & + & + & + & + & + & + & + & + & + & + & + & + & - \\
\hline AD2 & + & + & + & + & + & + & + & + & + & + & + & + & - \\
\hline AD3 & + & + & + & + & + & + & + & + & + & + & + & + & - \\
\hline AD4 & + & + & + & + & + & + & + & + & + & + & + & - & - \\
\hline AD5 & + & + & + & + & + & + & + & + & + & + & + & + & - \\
\hline AD6 & + & + & + & + & + & + & + & + & + & + & + & + & + \\
\hline AD7 & + & + & + & + & + & + & + & + & + & + & + & + & + \\
\hline AD8 & Slight & + & + & + & + & + & + & + & + & + & + & + & - \\
\hline AD9 & + & + & + & + & - & + & + & + & + & + & + & - & - \\
\hline AD10 & + & + & + & + & + & + & + & + & + & + & + & + & - \\
\hline AD11 & + & + & + & + & + & + & + & + & + & + & + & + & - \\
\hline AD12 & + & + & + & + & + & + & + & + & + & + & + & + & - \\
\hline AD13 & + & + & + & + & + & + & + & + & + & + & + & + & + \\
\hline AD14 & + & + & + & + & + & + & + & + & + & + & + & + & + \\
\hline AD15 & + & + & + & + & + & + & + & + & + & + & + & + & + \\
\hline AD16 & + & + & + & + & + & + & + & + & + & + & + & + & + \\
\hline AD17 & + & + & + & + & + & + & + & + & + & + & + & + & - \\
\hline AD18 & + & + & + & + & + & + & + & + & + & + & + & + & + \\
\hline AD19 & + & + & + & + & + & + & + & + & + & + & + & + & + \\
\hline AD20 & + & + & + & + & + & + & + & + & + & + & + & + & + \\
\hline AD21 & + & + & + & + & + & + & + & + & + & + & + & + & - \\
\hline AD22 & + & + & + & + & + & + & + & + & + & + & + & + & + \\
\hline AD23 & + & + & + & + & + & + & + & + & + & - & + & + & - \\
\hline AD24 & + & + & + & + & + & + & + & + & + & + & + & + & + \\
\hline AD28 & + & + & + & + & + & + & + & + & + & + & + & + & + \\
\hline AD30 & + & + & + & + & + & + & + & + & + & + & + & + & + \\
\hline AD31 & + & + & + & + & + & + & + & + & + & + & + & + & + \\
\hline AD32 & + & + & + & + & + & + & + & + & - & + & + & + & + \\
\hline
\end{tabular}

-: Negative, +: Positive.

and AD32) belong to the genus Lactobacillus, one isolate (AD30) belong to the genus Lactococcus and one isolate (AD28) belong to the genus Staphylococcus.

We also have investigated yogurt making potential of these twenty-eight bacterial isolates.
Among the twenty-eight isolates, except for Lactococcus and Lactobacillus, four identified isolates [Burkholderia sp. (AD3), Burkholderia sp. (AD5), Burkholderiasp.(AD13) and Sphingomonas sp. AD20)] and one unidentified isolate (AD17) were able to produce yogurt/yogurt-like product. 
The obtained yogurts/yogurt-like products by the genus Burkholderia could be due to their acid tolerance as this genus has a high acid tolerance and their distribution is strongly affected by pH (Tago et al. 2014, Stopnisek et al. 2014, Sermswan et al. 2015, Hall et al. 2015), which is in compliance with our results. On the other hand, there is no data available with the acid tolerance of the genus Sphingomonas.

It is known that bacteria and theirmetabolites can be used in many industrial mineral processing applications (Johnson \& Hallberg 2005, Olson et al. 2003). There are several bacterial isolates whose utilization have started long time ago in different bioleaching processes including Acidithiobacillus sp. (sulphides), Micobacteria phlei (haematite), Bacillus circulans (bauxite) and Burkholdaria sp. (iron) (Rawlings 2002, Rao \& Subramanian 2007, Groudev 1987, Delvasto et al. 2009). Recently investigates regarding utilization of microorganisms in ore enrichment processes gained importance due to increase in demand and decrease in high grade materials. Recently, the use of bacterial isolates including Pseudomonas oryzihabitans and Lactobacillus sp. in magnesite ores enrichment has been reported (Karaoglu et al. 2016, Yanmis et al. 2015). More recently, Enterobacter sp., Klebsiella sp., Leclercia sp. and Leclercia adecarboxylata have been shown to dissolve silisium in boron clay (Efe et al. 2019). According to the literature regarding the determination of bioleaching mechanism performed with alumina-silicate and calcium carbonate, organic acids were mainly responsible for the dissolution of the tested materials (Rezza et al. 2001, Efe et al. 2020). Considering the fact that yogurt/yogurtlike product producing bacterial isolates may also secrete organic acids, we investigated carbonate and silicate dissolution potential of the seventeen bacterial isolates.
The results of carbonate dissolution experiments showed that many of the bacterial isolates were able to dissolve carbonates. On the other hand, the silicate dissolving ability of the same bacterial isolates was less than that of carbonates dissolving ability. In fact, the dissolution of carbonates by lactic acid bacteria has previously been reported (Yanmis et al. 2015). Similarly, the carbonate dissolving phenomenon continuously occurs in nature via microbial activity (Ehrlich 1998, Friis et al. 2003, Tang et al. 2012). However, the dissolution capabilities of insoluble compounds (carbonates and silicates) via Burkholderia and Sphingomonas has not been published elsewhere.

Considering the previous reports and the data obtained in the current work, it can be concluded that the presence of genus Burkholderia and Sphingomonas is not expected in home-made yogurt samples. On the other hand, the presence of pathogenic bacteria, Staphylococcus, in the yogurt samples indicates contamination which could be due to milking with either dirty hands, collecting in dirty milking pails or un-cleaned udders. In this study, the partial bacterial diversity of home-made yogurt samples in Agri Province has been shown for the first time. Moreover, the preliminary tests in making yogurts showed that the five bacterial isolates (except for known LAB) have potential in making yogurt/yogurt-like products. However, further fermentation applications and pathogenic traits of these bacterial isolates should be investigated in order to illustrate the potential of these bacterial isolates as a new yogurt producer. Therefore, the determination of the organic acids and volatile compound profiles of the yogurt/yogurt-like products should be investigated. Furthermore, the mechanism(s) underlying the carbonates and silicates dissolving capabilities of the bacterial isolates should be investigated. 
Table VI. Carbonates and Silicates dissolution potential of the isolates.

\begin{tabular}{|c|c|c|c|c|c|}
\hline Isolate code & Nearest type strain & $\mathrm{CaCO}_{3}$ & $\mathrm{MgCO}_{3}$ & $\mathrm{CaSiO}_{3}$ & $\mathrm{MgSiO}_{3}$ \\
\hline AD2 & Burkholderia sp. & + & + & - & - \\
\hline AD3 & Burkholderia sp. & + & + & - & - \\
\hline AD4 & Sphingomonas sp. & + & + & - & - \\
\hline AD5 & Burkholderia sp. & + & + & - & - \\
\hline AD6 & Burkholderia sp. & - & - & - & - \\
\hline AD8 & Sphingomonas sp. & + & + & - & - \\
\hline AD10 & Sphingomonas sp. & + & + & - & - \\
\hline AD11 & Sphingomonas sp. & + & + & - & - \\
\hline AD12 & Sphingomonas sp. & + & + & - & - \\
\hline AD13 & Burkholderia sp. & + & Slight & + & - \\
\hline AD14 & Sphingomonas sp. & + & - & + & - \\
\hline AD20 & Sphingomonas sp. & + & - & + & - \\
\hline AD21 & Sphingomonas sp. & + & - & Slight & - \\
\hline AD28 & Staphylococcus epidermidis & - & + & - & - \\
\hline AD30 & Lactococcus lactis & + & - & + & - \\
\hline AD31 & Lactobacillus paracasei & + & + & + & + \\
\hline AD32 & Lactobacillus casei & + & - & + & + \\
\hline
\end{tabular}

-: Negative, +: Positive.

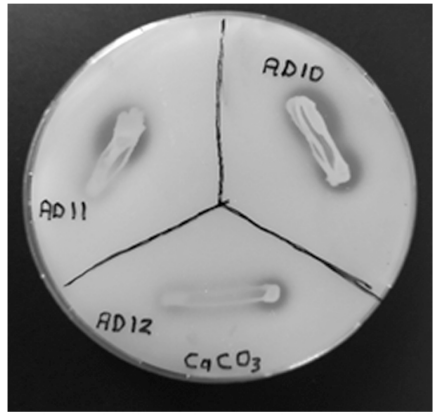

a: $\mathrm{CaCO}_{3}$

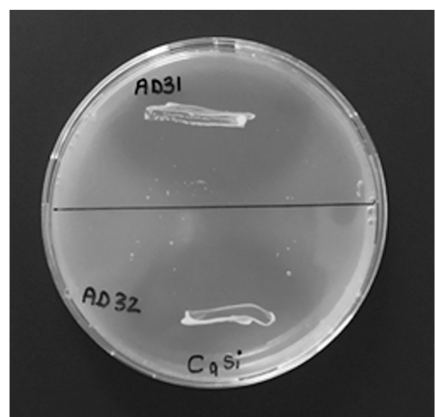

c: $\mathrm{CaSiO}_{3}$

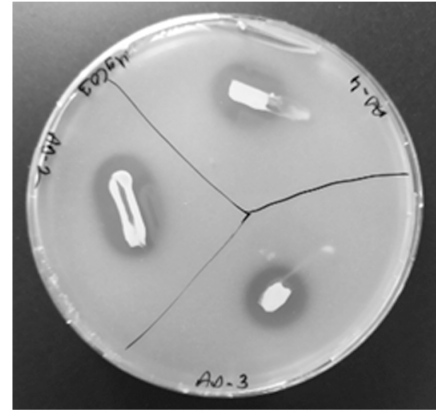

b: $\mathrm{MgCO}_{3}$

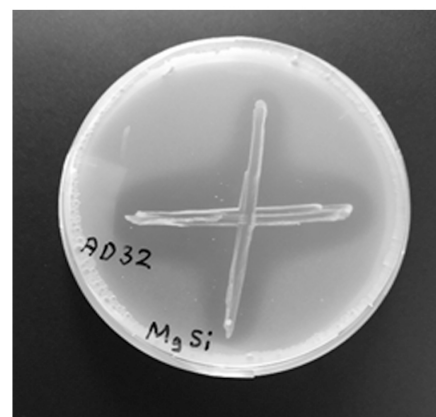

$\mathrm{d}: \mathrm{MgSiO}_{3}$
Figure 1. Carbonate and Silicate dissolving potential of the isolates.

a: $\mathrm{CaCO}_{3}$, b: $\mathrm{MgCO}_{3} \mathrm{c}: \mathrm{CaSiO}_{3}$ d: $\mathrm{MgSiO}_{3}$ containing media. 


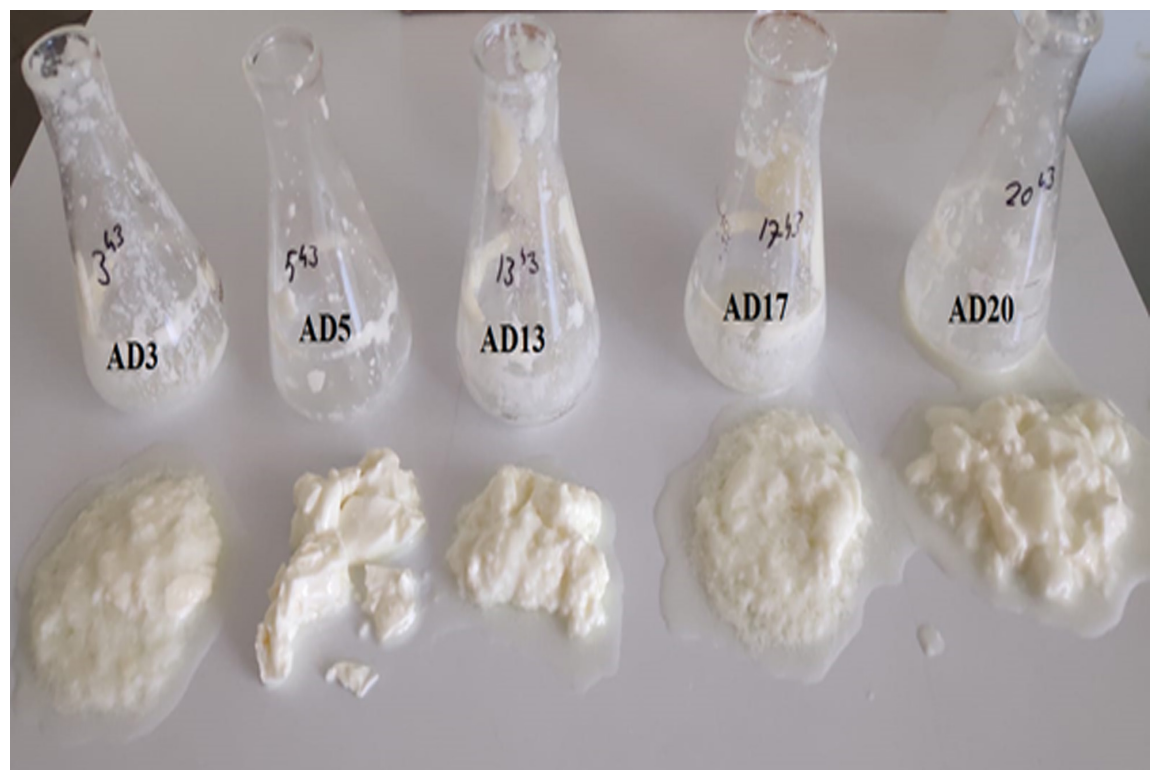

\author{
Figure 2. The bacterial \\ isolates producing \\ yogurt/yogurt-like \\ product.
}

\section{REFERENCES}

ASMA C \& QAZI J. 2014. Probiotic antagonism of Sphingomonas sp. against Vibrio anguillarum exposed Labeo rohita fingerlings. Adv Life Sci 4: 156-165.

ASTRUP A. 2014. Yogurt and dairy product consumption to prevent cardiometabolic diseases: epidemiologic and experimental studies. Am J Clin Nutr 99: 1235S-1242S.

AZADNIA P \& KHAN NAZER A. 2009. Identification of lactic acid bacteria isolated from traditional drinking yoghurt in tribes of Fars province. Iran J Vet Res 10: 235-240.

BARROW G \& FELTHAM RKA. 2004. Cowan and Steel's manual for the identification of medical bacteria. Cambridge Univ Pr.

BOWMAN JP, MCCAMMON SA, BROWN MV, NICHOLS DS \& MCMEEKIN TA. 1997. Diversity and association of psychrophilic bacteria in Antarctic sea ice. Appl Environ Microbiol 63: 3068-3078.

BUNT I \& ROVIRA A. 1955. Microbiological studies of some subantarctic soils. J Soil Sci 6: 119-128.

BURKHOLDER WH. 1950. Sour skin, a bacterial rot of onion bulbs. Phytopathology 40.

CACCHIO P, CONTENTO R, ERCOLE C, CAPPUCCIO G, MARTINEZ MP \& LEPIDI A. 2004. Involvement of microorganisms in the formation of carbonate speleothems in the Cervo Cave (L'Aquila-Italy). Geomicrobiol J 21: 497-509.

CHANDAN RC. 2015. Role of milk and dairy foods in nutrition and health. Dairy Proces Qual Ass: 428.
CHANDAN RC \& KILARA A. 2013. Manufacturing yogurt and fermented milks. Wiley Online Library.

CHILTON SN, BURTON JP \& REID G. 2015. Inclusion of fermented foods in food guides around the world. Nutrients 7: 390-404.

CHUARD C \& RELLER L. 1998. Bile-esculin test for presumptive identification of enterococci and streptococci: effects of bile concentration, inoculation technique, and incubation time. J Clinical Microbiol 36: 1135-1136.

DEETH H \& TAMIME A. 1981. Yogurt: nutritive and therapeutic aspects. J Food Prot 44: 78-86.

DELVASTO P, BALLESTER A, MUÑOZ J, GONZÁLEZ F, BLÁZQUEZ M, IGUAL J, VALVERDE A \& GARCÍA-BALBOA C. 2009. Mobilization of phosphorus from iron ore by the bacterium Burkholderia caribensis FeGL03. Miner Eng 22: 1-9.

DONOVAN SM \& SHAMIR R. 2014. Introduction to the yogurt in nutrition initiative and the First Global Summit on the health effects of yogurt. Am J Clin Nutr 99: 1209S-1211S.

EBERL L \& VANDAMME P. 2016. Members of the genus Burkholderia: good and bad guys. F1000Research 5.

EBRAHIMI MT, OUWEH AC, HEJAZI MA \& JAFARI P. 2011. Traditional Iranian dairy products: A source of potential probiotic lactobacilli. Afr J Microbiol Res 5: 20-27.

EFE D, ERTAN B, SAVAS M \& ORHAN F. 2019. Isolation and Identification of Bacteria with silicium dissolution ability from boron clay. Int J Sci Eng Res: 26-29. 
EFE D, ORHAN F, GULLUCE M \& SAHIN F. 2020. An Alternative Biotechnological Tool for Magnesite Enrichment: Lactic Acid Bacteria Isolated from Soil. Geomicrobiol J: 1-8.

EHRLICH HL. 1998. Geomicrobiology: its significance for geology. Earth Sci Rev 45: 45-60.

FERREIRA A, MORAIS P, GOMES C \& DA COSTA M. 1996. Computer-aided comparison of protein electrophoretic patterns for grouping and identification of heterotrophic bacteria from mineral water. J Appl Bacteriol 80: 479-486.

FRIIS A, DAVIS T, FIGUEIRA M, PAQUETTE J \& MUCCI A. 2003. Influence of Bacillus subtilis cell walls and EDTA on calcite dissolution rates and crystal surface features. Environ Sci Technol 37: 2376-2382.

GAUTHIER V, REDERCHER S \& BLOCK J-C. 1999. Chlorine Inactivation of SphingomonasCells Attached to Goethite Particles in Drinking Water. Appl Environ Microbiol 65: 355-357.

GELDREICH EE. 1996. Pathogenic agents in freshwater resources. Hydrol process 10: 315-333.

GROUDEV S. 1987. Use of heterotrophic microorganisms in mineral biotechnology. Acta Biotechnol 7: 299-306.

GURR M. 1987. Nutritional aspects of fermented milk products. FEMS Microbiol Rev 3: 337-342.

HALL CM, BUSCH JD, SHIPPY K, ALLENDER CJ, KAESTLI M, MAYO M, SAHL JW, SCHUPP JM, COLMAN RE \& KEIM P. 2015. Diverse Burkholderia species isolated from soils in the southern United States with no evidence of B. pseudomallei. PLoS ONE 10: e0143254.

HUNT KM, FOSTER JA, FORNEY LJ, SCHÜTTE UM, BECK DL, ABDO Z, FOX LK, WILLIAMS JE, MCGUIRE MK \& MCGUIRE MA. 2011. Characterization of the diversity and temporal stability of bacterial communities in human milk. PLOS ONE 6: e21313.

JOHNSON DB \& HALLBERG KB. 2005. Acid mine drainage remediation options: a review. Sci Total Environ 338: 3-14.

KARAOGLU H, YANMIS D \& GURKOK S. 2016. Magnesite enrichment with Pseudomonas oryzihabitans isolated from magnesite ore. Geomicrobiol J 33: 46-51.

KUEHN JS, GORDEN PJ, MUNRO D, RONG R, DONG Q, PLUMMER PJ, WANG C \& PHILLIPS GJ. 2013. Bacterial community profiling of milk samples as a means to understand culturenegative bovine clinical mastitis. PLoS ONE 8: e61959.

LEY RE, TURNBAUGH PJ, KLEIN S \& GORDON JI. 2006. Microbial ecology: human gut microbes associated with obesity. Nature 444: 1022.
MARETTE A \& PICARD-DELAND E. 2014. Yogurt consumption and impact on health: focus on children and cardiometabolic risk. Am J Clin Nutr 99: 1243S-1247S.

MORELLI L. 2014. Yogurt, living cultures, and gut health. Am J Clin Nutr 99: 1248S-1250S.

NAKHDJAVANI FA, MOAZAMI N \& LAMEA H. 1996. Growth inhibition of pathogens by lactic acid bacteria producing inhibitory substances. Med J Islam Repub Iran 10: 159-163.

OIE S, OOMAKI M, YORIOKA K, TATSUMI T, AMASAKI M, FUKUDA T, HAKUNO H, NAGANO K, MATSUDA M \& HIRATA N. 1998. Microbial contamination of 'sterile water'used in Japanese hospitals. J Hosp Infect 38: 61-65.

OLSON G, BRIERLEY J \& BRIERLEY C. 2003. Bioleaching review part B. Appl Microbiol Biot 63: 249-257.

ORHAN F \& GULLUCE M. 2015. Isolation and characterization of salt-tolerant bacterial strains in salt-affected soils of Erzurum, Turkey. Geomicrobiol J 32: 521-529.

PEYER LC, ZANNINI E \& ARENDT EK. 2016. Lactic acid bacteria as sensory biomodulators for fermented cereal-based beverages. Trends Food Sci Tech 54: 17-25.

RAO KH \& SUBRAMANIAN S. 2007. Bioflotation and bioflocculation of relevance to minerals bioprocessing. Microbial processing of metal sulfides: Springer, $p$. 267-286.

RAWLINGS DE. 2002. Heavy metal mining using microbes. Annu Rev Microbiol 56: 65-91.

REZZA I, SALINAS E, ELORZA M, DE TOSETTI MS \& DONATI E. 2001. Mechanisms involved in bioleaching of an aluminosilicate by heterotrophic microorganisms. Process Biochem 36: 495-500.

ROUND JL \& MAZMANIAN SK. 2009. The gut microbiota shapes intestinal immune responses during health and disease. Nature Rev Immunol 9: 313.

ROUSHANZADEH S, ESKANDARI M, SHEKARFOROUSH S \& HOSSEINI A. 2014. Phenotypic and genotypic diversity of dominant lactic acid bacteria isolated from traditional yoghurts produced by tribes of Iran. Iran J Vet Res 15: 347.

SERMSWAN RW, ROYROS P, KHAKHUM N, WONGRATANACHEEWIN S \& TUANYOK A. 2015. Direct detection of Burkholderia pseudomallei and biological factors in soil. Trans R Soc Trop Med Hyg 109: 462-468.

SHAH NP \& CHAMPAGNE CP. 2015. Cultured Milk and Yogurt. Dairy Proces Qual Ass: 235-265.

STOPNISEK N, BODENHAUSEN N, FREY B, FIERER N, EBERL L \& WEISSKOPF L. 2014. Genus-wide acid tolerance accounts 
for the biogeographical distribution of soil Burkholderia populations. Environ Microbiol 16: 1503-1512.

TABATA K, KASUYA K-I, ABE H, MASUDA K \& DOI Y. 1999. Poly (Aspartic Acid) Degradation by a Sphingomonas sp. Isolated from Freshwater. Appl Environ Microbiol 65: 4268-4270.

TAGO K, ITOH H, KIKUCHI Y, HORI T, SATO Y, NAGAYAMA A, OKUBO T, NAVARRO R, AOYAGI T \& HAYASHI K. 2014. A fine-scale phylogenetic analysis of free-living Burkholderia species in sugarcane field soil. Microbes Environ ME14122.

TAMIME A \& DEETH H. 1980. Yogurt: technology and biochemistry. J Food Protect 43: 939-977.

TANG Y, LIAN B, DONG H, LIU D \& HOU W. 2012. Endolithic bacterial communities in dolomite and limestone rocks from the Nanjiang Canyon in Guizhou karst area (China). Geomicrobiol J 29: 213-225.

TENORIO-SALGADO S, TINOCO R, VAZQUEZ-DUHALT R, CABALLERO-MELLADO J \& PEREZ-RUEDA E. 2013. Identification of volatile compounds produced by the bacterium Burkholderia tropica that inhibit the growth of fungal pathogens. Bioengineered 4: 236-243.

VACHÉE A, MOSSEL D \& LECLERC H. 1997. Antimicrobial activity among Pseudomonas and related strains of mineral water origin. J Appl Microbiol 83: 652-658.

VAN VT, BERGE O, KE SN, BALANDREAU J \& HEULIN T. 2000. Repeated beneficial effects of rice inoculation with a strain of Burkholderia vietnamiensison early and late yield components in low fertility sulphate acid soils of Vietnam. Plant Soil 218: 273-284.

VELIKOVA P, PETROV K, LOZANOV $V$, TSVETANOVA F, STOYANOV A, WU Z, LIU Z \& PETROVA P. 2018. Microbial diversity and health-promoting properties of the traditional Bulgarian yogurt. Biotechnol Biotechnol Equip 32: 1205-1217.

VIAL L, LÉPINE F, MILOT S, GROLEAU M-C, DEKIMPE V, WOODS DE \& DÉZIEL E. 2008. Burkholderia pseudomallei, B. thailandensis, and B. ambifaria produce 4-hydroxy-2alkylquinoline analogues with a methyl group at the 3 position that is required for quorum-sensing regulation. J Bacteriol 190: 5339-5352.

WAYNE L, ENGBAEK H, ENGEL H, FROMAN S, GROSS W, HAWKINS J, KÄPPLER W, KARLSON A, KLEEBERG H \& KRASNOW I. 1974. Highly reproducible techniques for use in systematic bacteriology in the genus Mycobacterium: tests for pigment, urease, resistance to sodium chloride, hydrolysis of Tween 80 , and $\beta$-galactosidase. Int J Syst Evol Microbiol 24: 412-419.
WAYNE P. 2002. National committee for clinical laboratory standards. Performance standards for antimicrobial disc susceptibility testing 12: 01-53.

WOOD WA \& KRIEG NR 1989. Methods for general and molecular bacteriology. ASM Press, Washington DC.

YANMIS D, ORHAN F, GULLUCE M \& SAHIN F. 2015. Biotechnological magnesite enrichment using a carbonate dissolving microorganism, Lactococcus sp. Int J Miner Process 144: 21-25.

ZHANG R, HUO W, ZHU W \& MAO S. 2015. Characterization of bacterial community of raw milk from dairy cows during subacute ruminal acidosis challenge by high-throughput sequencing. J Sci Food Agr 95: 1072-1079.

\section{How to cite}

ORHAN F, DEMIRCI A \& GORMEZ A. 2021. Carbonate and silicate dissolving bacteria isolated from home-made yogurt samples. An Acad Bras Cienc 93: e20200002. DOI 1.1590/0001-3765202120200002.

Manuscript received on January 8, 2020;

accepted for publicatiom on March 16, 2020

\section{FURKAN ORHAN ${ }^{1,2}$}

https://orcid.org/0000-0001-6906-6604

\section{ABDULLAH DEMIRCI ${ }^{2}$}

https://orcid.org/0000-0002-0422-5632

\section{ARZU GORMEZ ${ }^{3}$}

https://orcid.org/0000-0003-3246-1824

${ }^{1}$ Agri Ibrahim Cecen University, Science and Art Faculty, Molecular Biology and Genetics Department, 04100 Agri, Turkey ${ }^{2}$ Agri Ibrahim Cecen University, Central Research and Application Laboratory, 04100 Agri, Turkey ${ }^{3}$ Erzurum Technical University, Science Faculty, Molecular Biology and Genetics Department, 25050 Erzurum, Turkey

Correspondence to: Furkan Orhan

E-mail:furkan_orhan@hotmail.com

\section{Author contributions}

F.O. and A.D: performed the growth of bacterial isolates, biochemical and molecular tests; F.O: coordinated the study and wrote the manuscript; A.G: wrote the methods; all authors commented on and improved the manuscript.

\section{(cc) BY}

